\title{
Two new species of Meineckia Baill. (Phyllanthaceae) from Madagascar
}

\section{Hélène Ralimanana ${ }^{1}$}

Summary. Two new species of Meineckia (Phyllanthaceae) from Daraina, Madagascar, M. nusbaumeri and M. ranirisonii, are described and illustrated. Information on their distribution is provided and their conservation status is assessed.

Key Words. Daraina, endangered, IUCN conservation status, taxonomy.

\section{Introduction}

With 30 species, Meineckia Baill. is one of the largest genera in Phyllanthaceae Martynov tribe Poranthereae Grüning. It occurs in South and Central America, Africa, Madagascar, Socotra, the Arabian Peninsula, Sri Lanka and India. Meineckia was first recognised by Baillon (1858). Later, Müller (1865) considered it to be a synonym of Flueggea Willd. In Müller's treatment (Müller 1866 the representatives of modern Meineckia were placed in three different groups: Cluytiandra Müll. Arg., Phyllanthus L. and Securinega Comm. ex A. Juss. Later investigation by Webster (1965) based on herbarium material of these taxa showed that they belonged in a different genus to Phyllanthus, because of the annular disk and pistillode of the male flower, and to Securinega, because of the fused filaments and pitted seeds. Therefore, he took Baillon's name Meineckia which had prority over Cluytiandra.

Expansion of molecular studies of the Phyllanthaceae during the last ten years has brought a broader understanding of the phylogenetic relationships and circumscription of taxa in this family. The group Poranthereae is one of the 12 identified by Wurdack et al. (2004) and confirmed by Samuel et al. (2005), and Kathriarachchi et al. (2005). It was recognised at the tribal level as Poranthereae by Hoffmann et al. (2006), and the phylogenetic classification of the tribe and the circumscription of the groups within this tribe were studied by Vorontsova et al. (2007) and Vorontsova \& Hoffmann (2008). They recognised eight genera: Actephila Blume, Andrachne L., Leptopus Decne., Meineckia, Notoleptopus Voronts. \& Petra Hoffm., Phyllanthopsis (Scheele) Voronts. \& Petra Hoffm., Poranthera Rudge and Pseudophyllanthus (Müll. Arg.) Voronts. \& Petra Hoffm. Within Meineckia they recognised two subgenera: Meineckia subgen. Meineckia and M. subgen. Petaliferae Voronts. \& Petra Hoffm.

Prior to Webster's (1965) revision, Meineckia was not recognised in Madagascar because Leandri (1958), following Müller (1866), placed its species in Phyllanthus, Cluytiandra and Securinega. In his treatment Webster (1965) recognised 19 species of Meineckia, with eight of them from Madagascar: M. baronii (Hutch.) G. L. Webster, M. humbertii G. L. Webster, M. leandri G. L. Webster, M. madagascariensis (Leandri) G. L. Webster, M. orientalis (Leandri) G. L. Webster, M. peltata (Hutch.) G. L. Webster, M. pubiflora G. L. Webster and M. trichogynis (Baill.) G. L. Webster.

In 1982 Brunel \& Roux described one new species from Madagascar: Meineckia websteri Jean F. Brunel \& J. P. Roux. Radcliffe-Smith (1997) added M. decaryi (Leandri) Jean F. Brunel ex Radcl.-Sm. After studying the tribe Poranthereae Vorontsova \& Hoffmann (2008) recognised M. cerebroides (Petra Hoffm.) Voronts. \& Petra Hoffm. and M. gracilipes (Petra Hoffm.) Voronts. \& Petra Hoffm. In this paper two new species are described, bringing the total number of Meineckia species known from Madagascar to 14 . The genus occupies a wide range of habitats there, ranging from dry spiny, dry forest to rainforest.

Daraina, in the northwestern region of Madagascar, is an unusual place as it is situated on the boundaries of four phytogeographical domains defined by Humbert (1955): East, Centre, West and the Sambirano. The Daraina region includes steep environmental gradients and a complex topography (Bogner \& Nusbaumer 2012), resulting in the presence of a mixture of different types of vegetation in the same area: humid forest, dry forest and intermediate vegetation. The special

\footnotetext{
Accepted for publication 21 July 2017. Published online 6 September 2017

1 Kew Madagascar Conservation Centre, Royal Botanic Gardens, Kew, Lot II J 131 B Ambodivoanjo, 101, Antananarivo, Madagascar. e-mail: hralimanana.rbgkew@moov.mg
} 
character of this region has attracted scientists since the 1980s. Botanists from the Jardin Botanique de la Ville Genève (CGB) and the University of Antananarivo carried out extensive floristic inventories of the region from 2003 to 2006. Several new species have been published from their work, such as Carlephyton darainense Bogner \& Nusb.

Meineckia species have inconspicuous, small, green flowers. At first glance they may be mistaken for Phyllanthus, so material of Meineckia is often incorrectly named and misplaced in that genus. Two collections made by the Geneva botanists in Daraina were among unnamed collections of Phyllanthus at Kew. It was during the revision of the Madagascan Phyllanthus that they were identified as Meineckia. Examination of Meineckia type specimens held at the Muséum d'Histoire Naturelle, Paris, and of other collections at the Royal Botanic Gardens Kew, the Parc Botanique et Zoologique de Tsimbazaza, and Centre National de Recherche Appliquée au Développement Rural confirmed that these collections are clearly distinct from the species recognised by Webster (1965) and Brunel \& Roux (1982). I describe these species new to science as Meineckia nusbaumeri Ralim. sp. nov and $M$. ranirisonii Ralim. sp. nov. Considering the infrageneric classification given by Vorontsova \& Hoffmann (2008) and the morphological characters of the new species described, $M$. nusbaumeri belongs to the subgenus Petaliferae Voronts. \& Petra Hoffm., whereas M. ranirisonii belongs to subgenus Meineckia. Full descriptions, illustrations, distribution maps and conservation assessments are provided. Because of the seed ornamentation (cerebroïd or foveolate) and floral characters (presence or absence of petals and pigment on the sepals) these new species are compared with $M$. cerebroides and M. websteri.

\section{Materials and Methods}

Herbarium material of Madagascan Meineckia was consulted at the Muséum National d'Histoire Naturelle, Paris (P), Recherches Forestières et Piscicoles, Antananarivo (TEF), Parc Botanique et Zoologique de Tsimbazaza, Antananarivo (TAN), and the Royal Botanic Gardens, Kew (K). For the types, herbarium acronyms (following Thiers (continuously updated) are given and followed by an exclamation mark indicating that the specimens were seen by the author. The measurements and other details given in the descriptions are based mostly on dried specimens or softened plant parts. The floristic domains are as defined by Humbert (1965). The conservation status of each species was assessed by calculating the extent of occurrence using a GIS (Arcview 3.3), and applying the IUCN
Red List Category criteria (IUCN 2012). A list of material examined is given after each species description.

1. Meneckia nusbaumeri Ralim. sp. nov. Type: Madagascar: Antsiranana, Vohemar, Daraina, Solaniampialana-Maroadabo forest, $13^{\circ} 05.92^{\prime} \mathrm{S}$, 49³4.33'E, alt. 328 m, 6 Feb. 2006, Nusbaumer $\mathcal{E}$ Ranirison 2024 (holotype K!; isotypes G, TEF!).

http:/ /www.ipni.org/urn:Isid:ipni.org:names:77162514-1

Monoecious shrubs 1 - $1.5 \mathrm{~m}$ high; older branches greyish or green greyish, rough with lenticels, terete, young branches flattened, green, smooth and glabrous. Leaves: stipules persistent, ovate to triangular, $0.6-1 \times 0.3$ $-0.5 \mathrm{~mm}$, obtuse or acute at apex, coriaceous, fimbriate to laciniate, glabrous; petioles channelled above, $2-8 \times \mathrm{c}$. $0.4 \mathrm{~mm}$, glabrous; blades ovate, $1.5-6 \times 1.2-2.7 \mathrm{~cm}$, attenuate at the base, obtuse at the apex, thinly chartaceous, entire to slightly revolute, glabrous on both sides; midvein prominent on both sides, secondary veins 2 - 6 pairs, flattened adaxially, prominent abaxially, forming a $35^{\circ}-45^{\circ}$ angle with the midvein, tertiary veins inconspicuous. Inflorescences unisexual, consisting of $1-2$ male flowers or only 1 female flower; bracts in tufts of sterile bracts in male inflorescences, ovate, c. 0.2 $\times 0.1 \mathrm{~mm}$, erose to laciniate, glabrous. Male flowers c. $2 \times$ $2 \mathrm{~mm}$, greenish white when fresh; pedicels terete, $1.5-$ $2.5 \times$ c. $0.2 \mathrm{~mm}$, glabrous; sepals 5 , equal, $1.2-2.5 \times 0.2-$ $0.4 \mathrm{~mm}$, obovate, obtuse, rounded, or acute at the apex, membranous to subcoriaceous, glabrous or with few hairs, margins entire; petals $5,0.5-0.7 \times$ c. $0.3 \mathrm{~mm}$, oblong to oblanceolate, rounded at the apex, membranous, glabrous on both sides, margins entire; disc star-shaped, deeply 5-lobed, c. $1.3 \mathrm{~mm}$ across; stamens 5, fused into a column for $2 / 3_{3}-3 / 4$ of their length, column length $0.6-2 \mathrm{~mm}$, free part of filament $0.2-0.5 \times 0.2-0.4 \mathrm{~mm}$, curving, terete, anthers ovoid, c. $0.2 \mathrm{~mm}$ in diam., dehiscing longitudinally; pistillode angled, 3-lobed. $0.4-0.5 \mathrm{~mm}$ long. Female flowers c. $2 \times 3 \mathrm{~mm}$, greenish white when fresh; pedicels terete, becoming flattened toward the receptacle, c. $10 \times 0.3 \mathrm{~mm}$, glabrous; sepals 5 , subequal, ovate, $1-1.5$. $\times$ c. $1 \mathrm{~mm}$, obtuse at the apex, membranous to subcoriaceous, glabrous or with few hairs, margins entire; petals 5, $0.3-0.5$. × c. $0.3 \mathrm{~mm}$, obovate to obdeltate, rounded to retuse at the apex, membranous, glabrous on both sides, margins entire; disc irregularly lobed; ovary 3-locular, subglobose to oblate, c. $1.6 \times 2 \mathrm{~mm}$, rugose when dry, with fine and few sparse hairs; styles free, very short $0.3-0.4 \mathrm{~mm}$ long; stigmas capitate. Fruits (only seen dehisced) capsular, with fine and rare sparse hairs; fruiting pedicels c. $20 \times$ $0.3 \mathrm{~mm}$ (diam. $0.5 \mathrm{~mm}$ near the receptacle), glabrous or with sparse hairs; sepals persistent; columella persistent, 


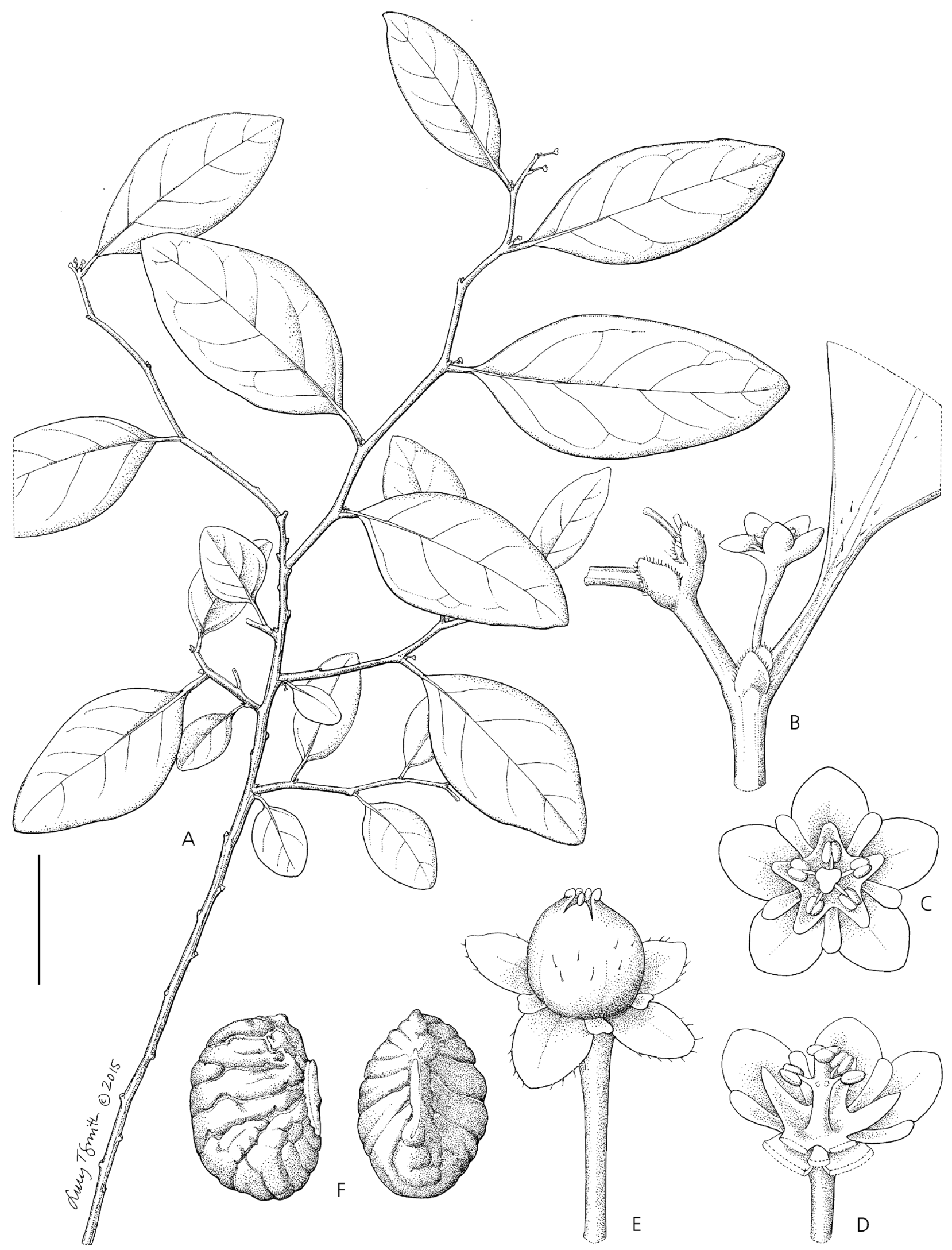

Fig. 1. Meineckia nusbaumeri. A habit (Ranirison 958, K); B stipule; C male flower from above; D male flower, 2 sepals and 1 petal removed; E young fruit; F seed, two views (Nusbaumer E Ranirison 2024, K). Scale bars: A 2 cm; B 2.2 mm; C - F 1.5 mm. DRAWN BY L. T. SMITH. 
angular, c. $2.5 \times 0.5 \mathrm{~mm}$. Seeds brown or greenish, $2-2.2 \times$ $1.3-1.8 \mathrm{~mm}$, rugose with cerebroïd ornamentation. Fig. 1.

RECOGNITION. Meineckia nusbaumeri is similar to $M$. cerebroides in its thinly chartaceous leaves, the lack of purplish pigment on its sepals, the presence of petals, fused stamens, and seeds with cerebroid ornamentation, but differs in its leaf blades that are attenuate at the base (vs obtuse to rounded) and obtuse at the apex (vs acuminate), sepals glabrous or with few hairs in female flowers (vs pubescent), male flower disc that is deeply lobed in a star-shape (vs shallowly lobed), and its ovary with a few hairs (vs pubescent).

DISTRIBUTION. Endemic to Madagascar: western floristic domains. Map 1.

SPECIMENS EXAMINED. MADAGASCAR. Antsiranana: Vohemar, Daraina, Bekaraoka forest, $13^{\circ} 10.51^{\prime} \mathrm{S}$, $49^{\circ} 44.00^{\prime} \mathrm{E}$, alt. $160 \mathrm{~m}$, March 2005, Ranirison $\mathcal{E}^{\circ}$ Nusbaumer 958 (G, K, TEF); Ambilobe, Ankarana, Manapisanga forest, $12^{\circ} 54^{\prime} 43^{\prime \prime S}, 49^{\circ} 10^{\prime} 18^{\prime \prime E}$, alt. 170 m, Feb. 2003, Vaucoulon 1424 (K, P).

HABITAT. Dry forest; alt. $150-350 \mathrm{~m}$.

CONSERVATION STATUS. Endangered (EN (Blabi-iv + B2abi-iv)). Meineckia nusbaumeri has an EOO of 798.67 $\mathrm{km}^{2}$ and an AOO of $12 \mathrm{~km}^{2}$. This species is threatened by habitat loss due to annual fire, forest logging, and

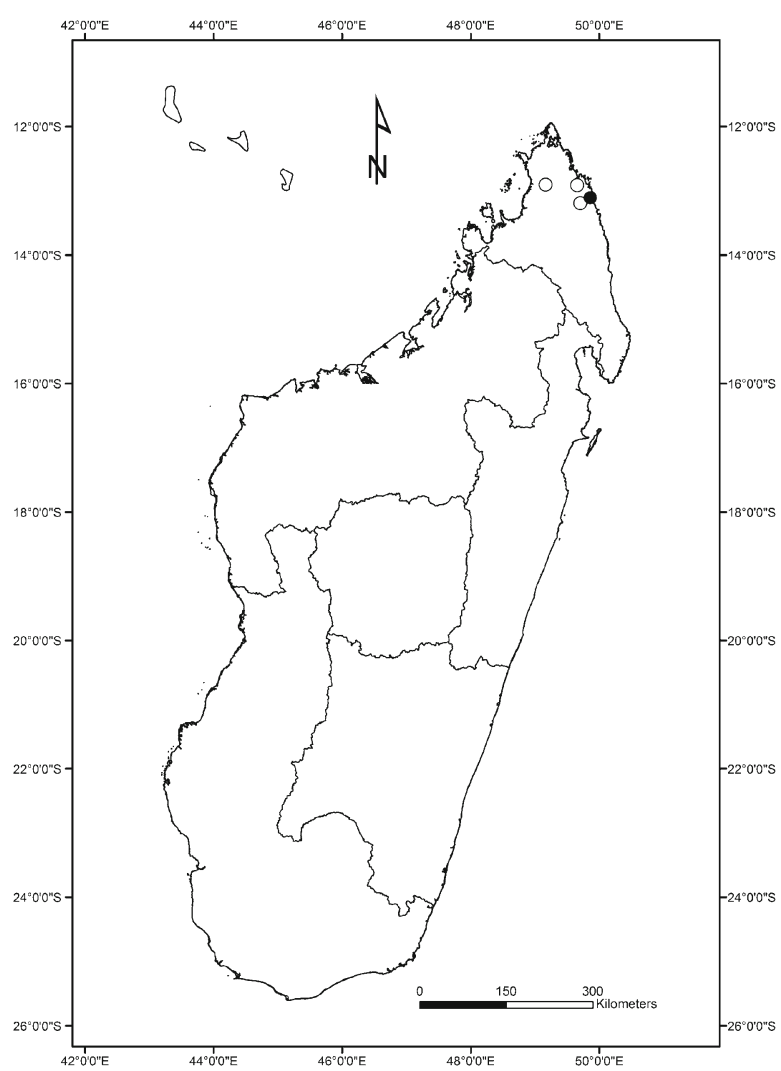

Map 1. Distribution of Meineckia nusbaumeri (open circles o) and $M$. ranirisonii (black circle $\bullet$ ). mining, which have led to a decline in the EOO, the AOO, the quality of the habitat, and the number of locations or subpopulations.

NOTES. Meineckia nusbaumeri was misidentified by the collector to Phyllanthus because of its long fruiting pedicel and the capsular fruit. The observations made on the male and female confirmed the presence of petals which are always absent in Phyllanthus. Filament fusion and the presence of pistillodes in male flowers confirmed that the collection belonged to Meineckia. The cerebroid ornamentation in seeds a rare character in Meineckia of Madagascar, it is found in M. cerebroides and $M$. gracilipes. However M. nusbaumeri is easily distinguished due to the disc deeply lobed and the ovary with very few hairs.

2. Meneckia ranirisonii Ralim. sp. nov. Type: Madagascar, Antsiranana, Vohemar, Daraina, Antsaharaingy forest, $12^{\circ} 54.25^{\prime} \mathrm{S}, 49^{\circ} 39.43^{\prime} \mathrm{E}$, alt. 65 m, 27 Feb. 2005, Nusbaumer E $\mathcal{F}^{2}$ Ranirison 1499 (holotype $\mathrm{K}$ !; isotypes $\mathrm{G}, \mathrm{TEF}$ !).

http:/ /www.ipni.org/urn:lsid:ipni.org:names:77162515-1

Monoecious shrubs $3 \mathrm{~m}$ high; older branches green blackish, rough, terete, young branches flattened, green, striate and glabrous. Leaves: stipules persistent, ovate to lanceolate, $0.5-1 \times 0.3-0.5 \mathrm{~mm}$, acute to attenuate at the apex, subcoriaceous, entire, glabrous; petioles channelled above, $3-5 \times$ c. $0.4 \mathrm{~mm}$, glabrous; blades widely ovate to elliptic, or oblong, $1.2-2.3 \times 0.8-$ $1.8 \mathrm{~cm}$, rounded and asymmetric at the base, obtuse at the apex, membranous, entire, glabrous on both sides; midvein flattened to slightly prominent adaxially, prominent abaxially, secondary veins $3-5$ pairs, flattened adaxially, slightly prominent abaxially, forming a $25^{\circ}-$ $35^{\circ}$ angle with the midvein; tertiary veins inconspicuous adaxially. Inflorescences unisexual, consisting of 1 male flower or 1 female flower; bracts, ovate, c. $0.2 \times 0.1 \mathrm{~mm}$, entire, glabrous. Male flowers c. $1.5 \times 1 \mathrm{~mm}$, greenish when fresh; pedicels terete, $4-6 \times$ c. $0.2 \mathrm{~mm}$, glabrous; sepals 5, equal, c. $1.5 \times 0.6 \mathrm{~mm}$, obovate, rounded, membranous, glabrous on both sides, margin entire; petals absent; disc annular, membranous to chartaceous, subentire, c. $0.5 \mathrm{~mm}$ high, c. $0.6 \mathrm{~mm}$ across; stamens 5 , fused into a column for $2 / 3$ of their length, c. $1 \times 0.3 \mathrm{~mm}$, the free part of filament curving, terete; anthers ovoid, $0.1-0.2 \mathrm{~mm}$ in diam., dehiscing longitudinally; pistillode sub-rounded, c. $0.3-0.4 \mathrm{~mm}$ long. Female flowers $1-1.3 \times 1.2-1.5 \mathrm{~mm}$, greenish when fresh. Pedicels terete, $40-50 \times$ c. $0.2 \mathrm{~mm}$, glabrous; sepals 5 , equal to subequal, ovate to elliptic, $0.5-1 \times 0.5-0.7 \mathrm{~mm}$, obtuse to rounded, sub-coriaceous, glabrous, margin entire; petals absent; disc irregularly lobed; ovary 3- 


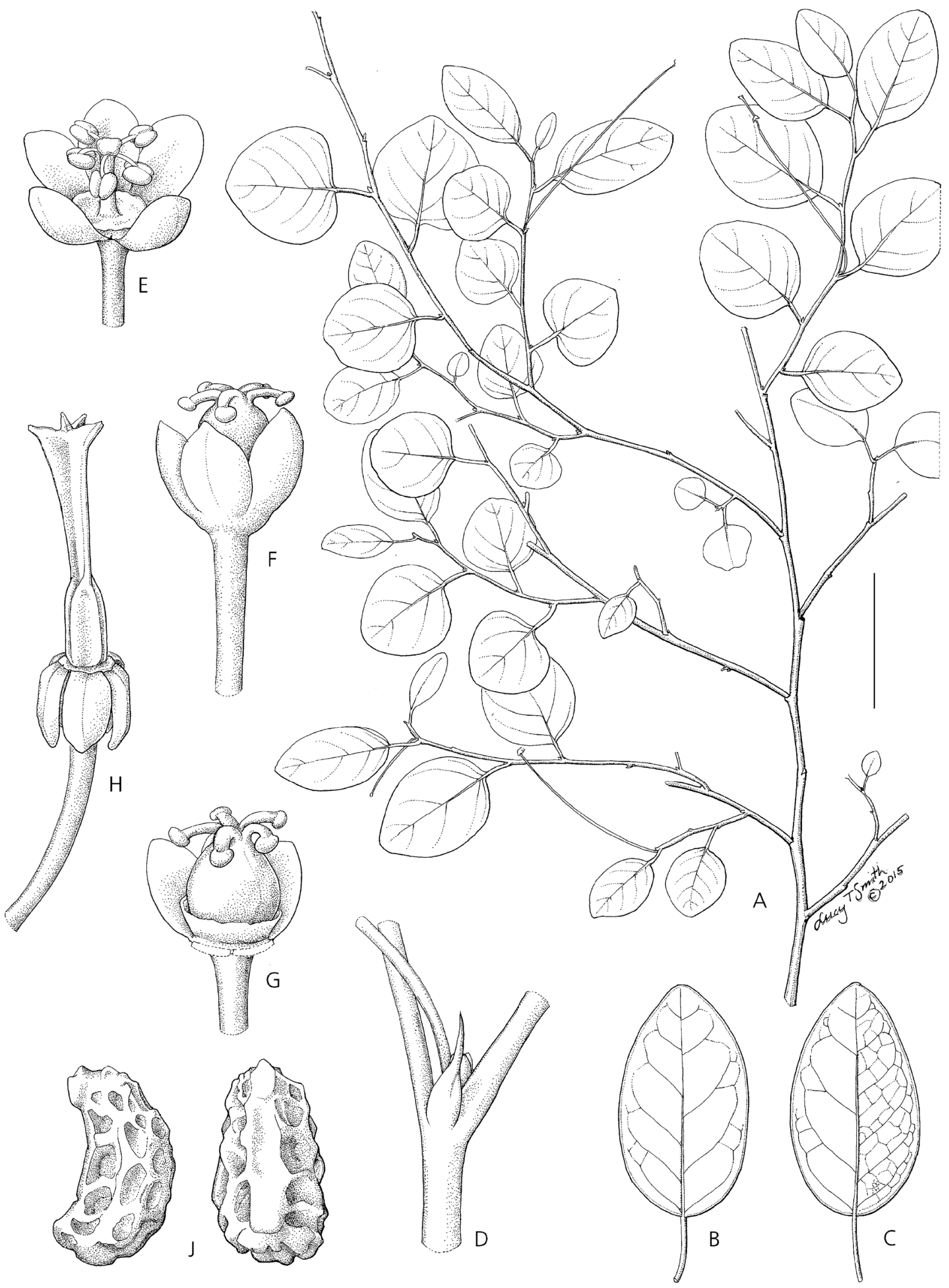

Fig. 2. Meineckia ranirisonii. A habit; B leaf adaxial surface; C leaf abaxial surface; D stipule; E male flower; $F$ female flower; $G$ female flower tepals removed; H columella; J seed, two views. Scale bars A 2 cm; B, C 1 cm; D 2.2 cm; E 0.9 mm; F, G 1.2 mm; H $1.5 \mathrm{~mm}$; J $1.6 \mathrm{~mm}$. From F. Rakotonasolo 803, TAN. DRAWN BY L. T. SMITH. 
locular, globose to ovoid, $0.7-1 \times 0.7-1 \mathrm{~mm}$, smooth, glabrous; styles free, bifid, c. $0.5-0.7 \mathrm{~mm}$ long; stigmas capitate. Fruits (only seen dehisced), capsular; fruiting pedicels $45-55 \times$ c. $0.2 \mathrm{~mm}$, glabrous; sepals persistent, $0.8-1.2 \times 0.5-0.7 \mathrm{~mm}$; columella persistent, angular, c. $3 \times 0.4 \mathrm{~mm}$. Seeds brown, $2-2.8 \times 1.3-1.5 \mathrm{~mm}$, foveolate. Fig. 2.

RECOGNITION. Meineckia ranirisonii is similar to M. websteri in its glabrous leaves, sepals without a dark purplish pigment, foveolate seeds, and absence of petals, but differs in being monoecious (vs dioecious), having leaf blades that are broadly ovate to elliptic or oblong leaf shape (vs mostly broadly ovate to suborbicular) and obtuse at the apex (vs emarginate), and its pedicels that are $4-5 \mathrm{~cm}$ long in flower and $4.5-5.5 \mathrm{~cm}$ long in fruit (vs $1.5-3 \mathrm{~cm}$ and $2.5-$ $3.5 \mathrm{~cm}$ long).

DISTRIBUTION. Endemic to Madagascar: western floristic domains. Map 1.

SPECIMEN EXAMINED. MADAGASCAR. Antsiranana, Vohemar, Daraina, Antsaharaingy forest, $12^{\circ} 54.25^{\prime} \mathrm{S}$, 49³9.43'E, alt. 65 m, 27 Feb. 2005, Nusbaumer $\mathcal{E}^{\circ}$ Ranirison 1499 (holotype K; isotypes G, TEF).

HABITAT. Dry forest; alt. $60 \mathrm{~m}$.

CONSERVATION STATUS. Vulnerable (VU (D2)). Meineckia ranirisonii is only known from the type, even though researchers have carried out collecting trips in the Daraina area. This species is assumed to be rare and with a very small population. In addition, wild fires frequently occur in this area.

NOTES. Meineckia ranirisonii was misidentified by the collectors to Phyllanthus because of its long fruiting pedicel and the capsular fruit. The observation made on the male flowers confirmed that it is Meineckia because of the annular disc and the presence of pistillodes. At first glance, $M$. ranirisonii may be mistaken for M. websteri. However, M. ranirisonii is easily recognised due to the obtuse leaf apex whereas it is emarginated in $M$. websteri. In addition the fruiting pedicels are distinctly longer in $M$. ranirisonii and the species grows in dry forest but not in littoral forest.

\section{Acknowledgements}

I would like to thank the Bentham-Moxon Trust and the Royal Botanic Gardens Kew who generously funded my visit to Kew and Paris. I also thank the curators and staff of K, P, TAN and TEF herbaria for placing at my disposal herbarium specimens of Meineckia. I acknowledge the botanists from Geneva who collected and provided the materials for identification. I am grateful to Lucy T. Smith (K) for the artwork.
Open Access This article is distributed under the terms of the Creative Commons Attribution 4.0 International License (http://creativecommons.org/ licenses/by/4.0/), which permits unrestricted use, distribution, and reproduction in any medium, provided you give appropriate credit to the original author(s) and the source, provide a link to the Creative Commons license, and indicate if changes were made.

\section{References}

Baillon, H. (1858). Étude générale du groupe des Euphorbiacées. Victor Masson, Paris.

Bogner, J. \& Nusbaumer, L. (2012). A new species of Carlephyton (Araceae) from northern Madagascar with notes on the species of this genus. Willdenowia. 42(2): 209 - 217.

Brunel, J. F. \& Roux, J. (1982). Phyllantheae de Madagascar III: une nouvelle espèce du genre Meineckia. Bull. Mus. Hist. Nat. Paris, Série 4, Section B, Adansonia 1 - 2: 79 - 84.

Humbert, H. (1955). Description des types de végétation. In: $H$. Humbert \& G. Cours-Darnes (eds), Notice de la carte de Madagascar. Trav. Sect. Sci. Techn. Inst. Franc., Pondichery, Extr. Hors Sér. 6: 46 - 78.

(1965). Les territoires phytogéographiques de Madagascar. Année Biol., Sér. 3(31): 439 - 448.

Hoffmann, P., Kathriarachchi, H. \& Wurdack, K. J. (2006). A phylogenetic classification of Phyllamtheae (Malpighiales; Euphorbiaceae sensu lato). Kew Bull. 61: 37 - 53.

IUCN (2012). IUCN Red List Categories and Criteria: version 3, second ed. IUCN Species Survival Commission, Gland and Cambridge.

Kathriarachchi, H., Hoffmann, P., Samuel, R., Wurdack, K. J. \& Chase, M. W. (2005). Molecular phylogenetics of Phyllanthaceae inferred from five genes (plastid atpB, matK, ndhF, rbcL, nuclear PHYC). Molec. Phylogenet. Evol. 36: 112 - 134.

Leandri, J. (1958). Euphorbiaceae I (Phyllanthoideae). In: H. Humbert (ed.), Flore de Madagascar et des Comores, 111ème famille: 1 199. Firmin-Didot, Paris.

Müller, J. (1865). Euphorbiaceae. Vorläufige Mittheilungen aus dem für De Candolle's Prodromus bestimmten Manuscript über diese Familie. Linnaea. 34: 1 - 224.

(1866). Euphorbiaceae. In: A. P. De Candolle (ed.), Prodromus systematis naturalis regni vegetabilis 15(2): 189 - 1286. Victor Masson, Paris.

Radcliffe-Smith, A. (1997). Notes on African and Madagascan Euphorbiaceae. Kew Bull. 52: 171 - 176.

Samuel, R., Kathriarachchi, H., Hoffmann, P., Barfuss, M. H. J., Wurdack, K. J., Davis, C. C. \& Chase, M. W. (2005). Molecular phylogenetics of Phyllanthaceae. 
Evidence from plastid matK and nuclear PHYC sequences. Amer. J. Bot. 92: 132 - 141.

Thiers, B. (continuously updated). Index Herbariorum: A global directory of public herbaria and associated staff. New York Botanical Garden's Virtual Herbarium. http://sweetgum.nybg.org/science/ih/.

Vorontsova, M. S., Hoffmann, P., Maurin, O. \& Chase, M. W. (2007). Molecular phylogenetics of tribe Poranthereae (Phyllanthaceae, Euphorbiaceae sensu lato). Amer. J. Bot. 94: 2026 - 2040.
\& Hoffmann, P. (2008). A phylogenetic classification of the tribe Poranthereae (Phyllanthaceae, Euphorbiaceae sensu lato). Kew. Bull. 63: 41 - 59.

Webster, G. L. (1965). A revision of the genus Meineckia (Euphorbiaceae). Acta. Bot. Neerl. 14: 323 - 365.

Wurdack, K. J., Samuel, R., de Bruijn, A., van der Bank, M. \& Chase, M. W. (2004). Molecular phylogenetic analysis of Phyllanthaceae (Phyllanthoideae pro parte, Euphorbiaceae sensu lato) using plastid rbcL DNA sequences. Amer. J. Bot. 92: 1397 - 1420. 